\title{
STRATEGI KOLABORASI DALAM SENI PERTUNJUKAN TRADISIONAL DI KABUpateN SUBANG
}

\section{COLLABORATION STRATEGIES IN TRADITIONAL PERFORMING ARTS IN SUBANG}

\author{
Oleh Irvan Setiawan \\ Balai Pelestarian Nilai Budaya Bandung \\ Jln. Cinambo No. 136 Ujungberung Bandung \\ Email: kamaliasetiawan@yahoo.co.id
}

\begin{abstract}
Abstrak
Kesenian tradisional memegang peranan dalam pencirian dan menjadi kekhasan suatu daerah. Bagi wilayah administratif yang menjadi cikal bakal suatu kesenian daerah tentu saja tidak sulit untuk menyebut istilah kesenian khas dan menjadi milik daerah tersebut. Lain halnya dengan wilayah administratif yang tidak memiliki kesenian daerah sehingga akan berusaha menciptakan sebuah kesenian untuk dijadikan sebagai kesenian khas bagi daerahnya. Beruntunglah bagi Kabupaten Subang yang menjadi cikal bakal beberapa kesenian yang terlahir dan besar di daerahnya. Tidak hanya sampai disitu, Pelestarian dan pengembangan kesenian tradisional tampak serius dilakukan. Hal tersebut terlihat dari papan nama berbagai kesenian (tradisional) di beberapa ruas jalan dalam wilayah Kabupaten Subang. Seiring berjalannya waktu tampak jelas terlihat adanya perubahan dalam pernak pernik atau tahapan pertunjukan pada beberapa seni pertunjukan tradisional. Kondisi tersebut pada akhirnya mengundang keingintahuan mengenai strategi kolaborasi apa yang membuat seni pertunjukan tradisional masih tetap diminati masyarakat Subang. Penelitian ini dilakukan dengan menggunakan metode deskriptif analisis yang didukung dengan data lintas waktu baik dari sumber sekunder maupun dari pernyataan informan mengenai seni pertunjukan tradisional di Kabupaten Subang. Dari hasil penelitian diperoleh bahwa kolaborasi yang dilakukan meliputi kolaborasi lintas waktu dan lintas ruang yang masih dibatasi oleh seperangkat aturan agar kolaborasi tidak melenceng dari identitas ketradisionalannya.
\end{abstract}

Kata kunci: Strategi kolaborasi, pertunjukan tradisional

\begin{abstract}
Traditional arts play a role in the characterization of a region. The Regency of Subang became the pioneer for inventing and creating some traditional arts. They were born and grew in the area, and their preservation and development are seriously taken into consideration. It is evident that some changes occurred over time, for example in the accessories or phase of performances at several traditional performing arts. This
\end{abstract}


condition makes the author curious about the strategy of collaboration that makes the people of Subang interested in traditional performing art. The author conducted descriptive analytical method supported by cross-time data either from primary or secondary sources. The result shows that the strategy of collaboration across time and space in traditional performing arts is limited by a set of rules so as not to deviate from its traditionality.

Keywords: collaboration strategy, traditional performing art

\section{A. PENDAhuluan}

Sisingaan, Doger Kontrak, dan Toleat merupakan beberapa kesenian daerah yang sudah sejak lama ada dan terlahir di tanah Subang. Selain tiga kesenian daerah tersebut, Subang masih memiliki kesenian tradisional yang hingga kini masih eksis dan berkembang seperti, Jaipong, Calung, Degung, Banjet, Gembyung, Kacapian, Kacapi Suling, Kacapi Siter, Tanjidor, Wayang Golek, Tayuban, Belentuk Ngapung, Topeng Menor, dan Tardug. Seluruh kesenian daerah di Kabupaten Subang tersebut bukan berarti hanya nama belaka. Ada organisasi atau grup yang hingga kini masih tetap berkecimpung khusus membidangi kesenian daerah.

Terlintas pertanyaan mengapa hingga kini masih ada individu atau sekelompok individu yang tetap bekerja hanya dengan mengandalkan pertunjukan kesenian yang dianggap kuno. Kontras terlihat apabila dibandingkan dengan daerah lain, terutama yang telah terkena imbas industrialisasi dan sebagian besar masyarakatnya mulai beralih profesi sebagai buruh. Pekerja seni yang ada kemudian sedikit demi sedikit mulai punah karena sudah kehilangan penggemar dan tentunya berimbas pada kesulitan pemenuhan kebutuhan hidup mereka.

Terlepas dari suka atau tidak suka terhadap sebuah kesenian daerah, Masyarakat Kabupaten Subang juga memiliki penilaian terhadap sebuah jenis kesenian. Mereka tentunya akan bosan menonton kesenian yang dianggap tidak menarik baik dari segi cerita, durasi, ataupun ornamen yang menghiasi panggung pertunjukan.

Meskipun demikian, penilaian masyarakat terhadap kesenian daerah tidak hanya didasarkan atas rasa suka atau tidak suka. Kultur dan persentase besaran pengaruh budaya global terhadap budaya lokal juga mendominasi alasan mengapa ada perbedaan karakteristik penilaian masyarakat terhadap kesenian daerah. Dalam dua penilaian tersebut, Kabupaten Subang juga secara langsung atau tidak langsung telah terkena imbas pengaruh budaya global. Wilayah Subang sebagaimana diketahui, adalah bagian dari 
wilayah yang dilalui jalur pantai utara, sebuah jalur utama transportasi darat pulau Jawa wilayah utara. Perilaku, nilai dan norma pengendara dan penumpang yang singgah di wilayah Subang sedikit banyak membawa pengaruh budaya kepada masyarakat sekitar. Selain itu, kondisi geografis Subang yang berbatasan dengan pantai utara Pulau Jawa juga secara tidak langsung memberi sumbangan pengaruh budaya lain terhadap budaya lokal masyarakat Subang. Sementara kondisi geografis bagian selatan Subang didominasi wilayah pegunungan yang memiliki potensi wisata sehingga mengundang para wisatawan untuk datang menikmati keindahan panorama Subang bagian selatan. Dampak dari segi budaya luar secara tidak langsung akan berpengaruh terhadap budaya masyarakat sekitar kawasan wisata tersebut.

Meski ada budaya luar (global) yang sangat mempengaruhi animo masyarakat Subang terhadap kesenian tradisional, ada satu kekuatan yang mendasari alasan mengapa hingga saat ini masih cukup banyak sanggar seni tradisional yang sangat berperan dalam pelestarian kesenian daerah di Subang. Kreativitas mereka terhadap seni tradisi melalui penciptaan ide penambahan perangkat atau alur cerita yang sesuai dengan kondisi saat ini atau bahkan menciptakan sebuah kesenian tradisional yang diambil dari kekayaan budaya di Subang. Ambil contoh salah satu kesenian daerah Subang, yaitu Belentuk Ngapung. Kesenian ini mulai dikenal - atau diciptakan - sekitar tahun 1950. Sementara itu, Sisingaan yang menjadi maskot kebanggan Kabupaten Subang memang terlahir masih eksis dan berkembang. Diperkirakan kesenian Sisingaan lahir sejak zaman penjajahan (Belanda dan Inggris) mengingat dua patung singa yang diarak merupakan simbol keangkuhan dua negara yang pernah menjajah Bangsa Indonesia. Genjring Bonyok, sebuah kesenian Genjring yang berasal dari Bonyok - nama daerah di dalam wilayah Desa Pangsor, yaitu Kampung Bonyok, Kecamatan Pagaden Kabupaten Subang. Demikian juga halnya dengan Toleat, sebuah kesenian daerah yang terlahir dari kreativitas penggembala kerbau di daerah Sukamandi Kabupaten Subang.

Selain kesenian asli Subang, ada juga kesenian yang dibawa dari daerah lain dan dikolaborasikan dengan kultur masyarakat Subang. Salah satunya adalah Topeng Menor, sebuah seni Topeng yang berasal dari Desa Jati Kecamatan Cipunegara Kabupaten Subang. Kesenian Topeng Menor yang juga diberi embel-embel nama daerah asalnya, menjadi Topeng Menor Cipunegara, merupakan perkawinan tari topeng gaya Cerbonan dan gaya Indramayuan sebagai buah kreasi dari Sutawijaya (dalang wayang kulit Indramayu) dan Mimi Sani (penari topeng Cirebon) yang menetap di Desa Jati Kecamatan Cipunegara Kabupaten Subang. 
Tanggapan positif dari Pemerintah Daerah Kabupaten Subang terhadap banyaknya kesenian tradisional yang masih bertahan dan berkembang di antaranya upaya mempatenkan empat kesenian tradisional khas Subang, yaitu Sisingaan, Banjet, Genjring Bonyok, dan Toleat.

Keempat kesenian daerah yang hendak dipatenkan tersebut bukan berarti tidak mengalami perubahan dari mulai awal penciptaan hingga saat ini. Ada bentuk-bentuk baru yang dikolaborasikan dengan kesenian asli sehingga tercipta sebuah kesenian daerah yang menarik dan menjadi perhatian masyarakat Subang. Kolaborasi yang diterapkan bukan hanya sekedar tempelan pada kesenian asli tanpa mempertimbangkan berbagai aspek.

Tempelan atau diistilahkan sebagai kolaborasi pada kesenian daerah di Kabupaten Subang tentunya didasarkan atas berbagai pertimbangan baik dari unsur seni ataupun ada rambu-rambu tradisi yang membatasi sampai seberapa jauh kolaborasi pada suatu kesenian daerah dapat dilakukan. Berdasarkan hal tersebut, penelitian ini akan membatasi pada masalah:

1. Jenis/asesoris/unsur kesenian apa yang dikolaborasikan pada kesenian daerah di Kabupaten Subang?

2. Pengaruh tradisi yang membatasi kolaborasi atau perubahan yang diperbolehkan terhadap suatu kesenian daerah di Kabupaten Subang?

Maksud penelitian ini adalah menelusuri, mendeskripsikan, dan menganalisis kiat-kiat warga masyarakat untuk mengkolaborasi kesenian tradisional di Kabupaten Subang. Tujuan Penelitian adalah untuk memperoleh data yang komprehensif berikut analisa data yang terkait dengan strategi kolaborasi sebagai upaya meningkatkan minat masyarakat terhadap seni pertunjukan tradisional di Kabupaten Subang).

Kolaborasi dapat diartikan sebagai penambahan bentuk lain dalam sebuah kesenian dengan tujuan agar kesenian tersebut dapat lebih menarik penonton tanpa meninggalkan nilai estetis dan makna dari kesenian itu sendiri. Saat ini banyak kesenian tradisional yang hampir punah karena para pekerja seni tersebut enggan untuk menerapkan pola baru pada keseniannya. Mereka lebih memilih pada keutuhan pakem yang berakibat animo penonton akan semakin berkurang. Apabila mereka menonton pun sebentar saja sudah menimbulkan kebosanan.

Meskipun demikian, ada koridor tertentu yang membatasi kolaborasi seni, utamanya mengkolaborasikan seni dari dua atau lebih daerah yang berbeda karakter budayanya. Hal ini senada dengan yang diungkapkan oleh filsuf Perancis, Michel 
Foucault, bahwa tiap komunitas punya paradigma sendiri yang berbeda dengan paradigma komunitas lain. Paradigma ini melahirkan jenis bunyi yang enak di dengar, tari yang enak dilihat, dan seterusnya, dan standar ini tentu tak sama per penampilan daerah. Dengan demikian, strategi disusun harus mengacu pada koridor-koridor yang telah ditentukan.

Membayangkan sebuah kesenian tradisional yang telah dikolaborasikan tentunya harus memiliki data awal saat suatu kesenian tradisional tercipta. Asumsi tahun tercipta mungkin dapat dikesampingkan karena penciptaan sebuah karya seni sangat minim dalam pengarsipan (tertulis). Hanya data lisan mengenai pendiri atau pencipta sebuah karya seni sebagian besar sudah wafat. Dari data awal karya seni tradisional tersebut kemudian dapat dilihat berbagai jenis kolaborasi seni yang berjalan dari awal penciptaan hingga saat ini. Gambaran data yang nantinya diperlukan dalam penelitian tersebut harus diantisipasi dengan menggunakan metode penelitian yang akurat agar hasil yang diperoleh minimal mendekati validitas keakuratan data. Dua jenis data yang diperlukan yaitu kondisi awal dan kondisi kekinian suatu kesenian tradisional, mengarahkan metode penelitian pada metode deskripsi komparasi, yaitu perbandingan antar data. Walaupun demikian, sifat penelitian ini tidaklah mengandalkan data kuantitatif karena data yang diperoleh lebih mengandalkan data kualitatif. Pengertian dari data kualitatif dapat dilihat, misalnya, dari sebuah kostum nayaga pada masa awal terciptanya kesenian yang dibandingkan dengan konstum nayaga pada kondisi kekinian. Tentunya, deskripsi dari mulai pernak pernik kostum, bahan yang digunakan, serta segi tradisi yang menjadi rambu-rambu pembuatan kostum patut dideskripsikan. Data tersebut sangat sulit untuk dijadikan sebagai data kuantitatif.

Mengingat data yang diperlukan sangat mengandalkan data dari jenis kualitatif, harus didukung perangkat pencarian dan perekam data yang mencukupi seperti, pedoman wawancara, perekam audio, dan perekam gambar (kamera). Pencarian data dilakukan dengan menggunakan teknik snowball sampling, artinya, sebuah data yang dirasa kurang lengkap akan ditelusuri dengan mengandalkan informasi dari informan atau sumber data awal yang memberi petunjuk ke arah sumber data lainnya. Data yang diperoleh nantinya akan terbagi menjadi dua jenis, yaitu data sekunder dan data primer. Data sekunder dapat diperoleh dari sumber tertulis dan data digital. 
B. HASIL DAN BAHASAN

\section{Gambaran Umum Lokasi Penelitian}

\section{a. Keadaan Alam}

Wilayah Kabupaten Subang mempunyai luas 205.176 Ha, meliputi 20 kecamatan, 2 perwakilan kecamatan (kemantren), 8 kelurahan dan 242 desa. Kabupatn Subang terletak pada posisi $107^{\circ} 31^{\prime}$ - $107^{\circ} 54^{\prime}$ Bujur Timur, $6^{\circ} 11^{\prime}-6^{\circ} 49^{\prime}$ Lintang Selatan. Batas-batas administratif Kabupaten Subang adalah sebagai berikut :

$\begin{array}{ll}\text { Sebelah utara } & \text { : Laut Jawa } \\ \text { Sebelah barat } & \text { : Kabupaten Purwakarta, Kabupaten Karawang } \\ \text { Sebelah selatan } & \text { : Kabupaten Bandung Barat } \\ \text { Sebelah timur } & \text { : Kabupaten Indramayu dan Kabupaten Sumedang }\end{array}$

Sementara itu, apabila dilihat dari kondiri topografis, Kabupaten Subang memiliki 3 zone daerah yang memiliki ketinggian antara $0-1.500 \mathrm{~m} \mathrm{dpl}$, yaitu : pegunungan, perbukitan, dan dataran rendah. Daerah pegunungan dengan ketinggian antara 500-1.500 m dpl, merupakan daerah resapan air. Lokasi : Kecamatan Jalancagak, Sagalaherang, Cisalak dan Tanjungsiang. Daerah bergelombang/berbukit dengan ketinggian antara 50-500 m dpl merupakan daerah penyangga. Lokasi : Kecamatan Subang, Cibogo, Cijambe, Cipunagara, Pagaden, Kalijati dan Cipeundeuy. Daerah pedataran sampai pantai Laut Jawa dengan ketinggian 0-50 m dpl merupakan daerah pengembangan / budidaya. Lokasi : Kecamatan Binong, Compreng, Pusakanagara, Pamanukan, Ciasem, Blanakan, Pabuaran, Patokbeusi, Perwakilan Kecamatan Legon kulon dan Cikaum.

\section{b. Kependudukan}

Menurut jenis kelamin, Jumlah penduduk Kabupaten Subang pada tahun 2010 sebesar 739,925 jiwa yang terbagi atas 725,232 laki-laki dan 1,465,157 perempuan. Sementara itu, untuk melihat jumlah penduduk berdasarkan kecamatan dapat dilihat dari tabel di bawah ini:

\section{TABEL 1}

Jumlah Penduduk Kabupaten Subang

berdasarkan Jenis Kelamin Tahun 2010

\begin{tabular}{|l|l|r|r|r|}
\hline No & \multicolumn{1}{|c|}{ Kecamatan } & \multicolumn{1}{c|}{ Laki-laki } & perempuan & \multicolumn{1}{c|}{ Jumlah } \\
\hline 1. & Sagalaherang & 14.325 & 14.406 & 28.731 \\
\hline 2. & Serangpanjang & 12.166 & 11.917 & 24.083 \\
\hline 3. & Jalancagak & 21.015 & 21.006 & 42.021 \\
\hline
\end{tabular}




\begin{tabular}{|l|l|r|r|r|}
\hline 4. & Ciater & 13.895 & 13.763 & 27.658 \\
\hline 5. & Cisalak & 19.299 & 19.018 & 38.317 \\
\hline 6. & Kasomalang & 20.183 & 19.629 & 39.812 \\
\hline 7. & Cijambe & 19.382 & 19.045 & 38.427 \\
\hline 8. & Cibogo & 19957 & 20513 & 40470 \\
\hline 9. & Subang & 61.061 & 59.285 & 120.346 \\
\hline 10. & Kalijati & 29.105 & 29.887 & 58.992 \\
\hline 11. & Dawuan & 18.892 & 19.006 & 37.898 \\
\hline 12. & Cipeundeuy & 22.246 & 22.348 & 44.594 \\
\hline 13. & Pabuaran & 29.997 & 29.822 & 59.819 \\
\hline 14. & Patokbeusi & 38.872 & 38.126 & 76.998 \\
\hline
\end{tabular}

Sumber : Rekapitulasi Data Statistik 14 Kecamatan dalam wilayah Kabupaten Subang Tahun 2011

Dalam tabel 1 di atas dapat dilihat bahwa jumlah penduduk terbanyak ada di kecamatan Subang dengan perbandingan yang tergolong seimbang antara laki-laki (61.061 orang) dan perempuan (59.285 orang). Sementara jumlah penduduk yang paling sedikit ada di Kecamatan Serangpanjang yang hanya berjumlah 24.083 orang terbagi atas 12.166 laki-laki dan 11.917 perempuan. Jumlah penduduk Kecamatan Subang yang cukup padat tersebut wajar terjadi karena Kecamatan Subang adalah ibukota Kabupaten Subang yang merupakan pusat perkantoran dan perniagaan. Berbeda halnya dengan Kecamatan Serangpanjang yang pada bagian Barat berbatasan langsung dengan Kabupaten Purwakarta yang sebagian besar lahannya banyak digunakan sebagai lahan pertanian dengan kontur wilayah yang berbukit-bukit.

Meski jumlah penduduk Kecamatan Serangpanjang paling sedikit di antara kecamatan lainnya (24.083 jiwa) namun apabila dilihat dari segi kepadatan per $\mathrm{km}^{2}$, Kecamatan Serangpanjang tergolong cukup padat $\left(43,9 \mathrm{Km}^{2}\right)$. Sementara jumlah penduduk Kecamatan Kalijati yang lebih dari dua kali lipat jumlah penduduk Kecamatan Serangpanjang (58.992 jiwa) tergolong paling sedikit tingkat kepadatan per $\mathrm{km}^{2}(83,23$ $\mathrm{Km}^{2}$. Untuk lebih jelasnya mengenai luas wilayah seluruh kecamatan di Kabupaten Subang dapat dilihat pada tabel 2 di bawah ini.

TABEL 2

Jumlah Penduduk Kabupaten Subang

berdasarkan Luas Desa, dan Kepadatan Tahun 2010

\begin{tabular}{|c|c|c|c|c|}
\hline No & Kecamatan & \begin{tabular}{|} 
Jumlah Penduduk \\
(Jiwa)
\end{tabular} & Luas $\left(\mathrm{Km}^{2}\right)$ & $\begin{array}{l}\text { Kepadatan } \\
\left(\mathbf{J i w a} / \mathbf{K m}^{2}\right)\end{array}$ \\
\hline 1. & Sagalaherang & 28.731 & 49.7 & $5.779,22$ \\
\hline 2. & Serangpanjang & 24.083 & 43.9 & $4.040,32$ \\
\hline
\end{tabular}




\begin{tabular}{|l|l|r|r|r|}
\hline 3. & Jalancagak & 42.021 & 36,83 & $1.141,00$ \\
\hline 4. & Ciater & 27.658 & 47,18 & 586,00 \\
\hline 5. & Cisalak & 38.317 & 76,59 & 8465,22 \\
\hline 6. & Kasomalang & 39.812 & 39,44 & $11.026,53$ \\
\hline 7. & Cijambe & 38.427 & 93,63 & 410,00 \\
\hline 8. & Cibogo & 40470 & 53,71 & 753,00 \\
\hline 9. & Subang & 120.346 & 58,70 & 25.622 \\
\hline 10. & Kalijati & 58.992 & 83,23 & $1.020,00$ \\
\hline 11. & Dawuan & 37.898 & $6.506,52$ & 71,18 \\
\hline 12. & Cipeundeuy & 44.594 & 92,66 & 481,00 \\
\hline 13. & Pabuaran & 59.819 & 76.89 & 778,00 \\
\hline 14. & Patokbeusi & 76.998 & 80.57 & $10.151,00$ \\
\hline
\end{tabular}

Sumber: Rekapitulasi Data Statistik 14 Kecamatan dalam wilayah Kabupaten Subang Tahun 2011

Pada tabel 2 di atas terlihat bahwa wilayah kecamatan paling luas ada di Kecamatan Dawuan, yaitu 6.506,52 $\mathrm{km}^{2}$, sedangkan luas wilayah kecamatan paling kecil adalah Kecamatan Serangpanjang yang hanya $43,9 \mathrm{~km}^{2}$. Korelasi antara jumlah penduduk dengan luas wilayah adalah pada tingkat kepadatan penduduknya. Hal demikian kemudian berpengaruh pada tingkat kepadatan penduduk di Kecamatan Dawuan yang hanya berjumlah 71,18 jiwa per $\mathrm{km}^{2}$. Sementara jumlah kepadatan penduduk yang paling tinggi ada pada Kecamatan Kasomalang dengan jumlah penduduk 39.812 orang yang menempati wilayah seluas $39,44 \mathrm{~km}^{2}$, sehingga kepadatannya tergolong tinggi yaitu mencapai $11.026,53$ per $\mathrm{km}^{2}$.

\section{c. Sosial Budaya}

Kondisi sosial budaya Kabupaten Subang dalam hal ini hanya dilihat dari dua jenis yaitu agama dan kelompok sosial. Hal ini dilandasi dari kedudukan agama yang mendapat tempat pertama dalam Pancasila, sedangkan kelompok sosial lebih mengarah pada keaktifan masyarakat terhadap bidang yang disenanginya yang menandakan keikutsertaan warga terhadap dinamika kehidupan sosial budaya masyarakat Kabupaten Subang.

Dalam bidang agama, sebagian besar warga Kabupaten Subang menganut agama Islam, sedangkan selebihnya (dalam jumlah yang relatif sedikit) ada juga warga yang menganut agama Kristen (2.394 orang), Katolik (1.002 orang), Hindu (76 orang), Budha (61 orang), dan Konghucu (4 orang). Jumlah penganut Islam bervariasi di antara kecamatan seperti yang terlihat pada tabel 3 di bawah ini.

\section{TABEL 3}


Jumlah Penganut Agama Kabupaten Subang Tahun 2010

\begin{tabular}{|l|l|r|r|r|r|r|r|}
\hline No & \multicolumn{1}{|c|}{ Kecamatan } & Islam & Kristen & Katolik & Hindu & Budha & $\begin{array}{c}\text { Khong } \\
\text { Hucu }\end{array}$ \\
\hline 1. & Sagalaherang & 28.725 & 6 & 0 & 0 & 0 & 0 \\
\hline 2. & Serangpanjang & 26.493 & 0 & 0 & 0 & 0 & 0 \\
\hline 3. & Jalancagak & 41.946 & 70 & 5 & 0 & 0 & 0 \\
\hline 4. & Ciater & 24.870 & 28 & 19 & 0 & 1 & 0 \\
\hline 5. & Cisalak & 38.317 & 0 & 0 & 0 & 0 & 0 \\
\hline 6. & Kasomalang & 39.797 & 0 & 15 & 0 & 0 & 0 \\
\hline 7. & Cijambe & 38.380 & 39 & 8 & 0 & 0 & 0 \\
\hline 8. & Cibogo & 40462 & 8 & 0 & 0 & 0 & 0 \\
\hline 9. & Subang & 118.198 & 1.479 & 587 & 41 & 37 & 4 \\
\hline 10. & Kalijati & 58.021 & 563 & 360 & 33 & 15 & 0 \\
\hline 11. & Dawuan & 37.891 & 7 & 0 & 0 & 0 & 0 \\
\hline 12. & Cipeundeuy & 40.231 & 83 & 2 & 0 & 3 & 0 \\
\hline 13. & Pabuaran & 59.786 & 23 & 0 & 0 & 0 & 0 \\
\hline 14. & Patokbeusi & 76.876 & 88 & 6 & 2 & 5 & 0 \\
\hline
\end{tabular}

Sumber: Rekapitulasi Data Statistik 14 Kecamatan dalam wilayah Kabupaten Subang Tahun 2011

Jumlah penganut Islam terbanyak ada di Kecamatan Subang, yaitu mencapai 118.198 orang, sedangkan yang paling sedikit ada di Kecamatan Serangpanjang yaitu hanya mencapai 26.493 orang. Namun demikian, variasi tersebut bukan menjadi patokan dari klasifikasi banyak atau sedikitnya jumlah penganut agama Islam karena harus dibagi dari persentase jumlah keseluruhan penduduk pada masing-masing kecamatan. Dengan demikian, meskipun memiliki jumlah penganut Islam paling sedikit, namun Kecamatan Serangpanjang tidak memiliki penganut agama lainnya atau dengan kata lain seluruh warga Serangpanjang menganut agama Islam. Berbeda halnya dengan Kecamatan Subang yang meskipun paling banyak jumlah penganut Islamnya, namun cukup banyak juga penganut agama lainnya.

Beralih ke bidang kelompok sosial, Warga Subang ternyata cukup aktif dalam membentuk kelompok-kelompok sosial dan ditingkatkan menjadi organisasi sosial. Empat jenis organisasi sosial yang dapat dilihat pada tabel 4 di bawah ini mencakup bidang kesenian, olahraga, karang Taruna, dan lain-lain.

TABEL 4

Jumlah Organisasi di Kabupaten Subang menurut Jenis dan Anggotanya Tahun 2010

\begin{tabular}{|c|c|c|c|c|c|}
\hline No & Kecamatan & Kesenian & $\begin{array}{l}\text { Olah } \\
\text { Raga }\end{array}$ & $\begin{array}{l}\text { Karang } \\
\text { Taruna }\end{array}$ & Lain-lain \\
\hline
\end{tabular}




\begin{tabular}{|c|c|c|c|c|c|c|c|c|c|}
\hline & & \begin{tabular}{|l} 
Jumla \\
h
\end{tabular} & \begin{tabular}{|l|} 
Anggot \\
a
\end{tabular} & $\begin{array}{l}\text { Jumla } \\
\text { h }\end{array}$ & $\begin{array}{l}\text { Anggot } \\
\text { a }\end{array}$ & $\begin{array}{l}\text { Jumla } \\
\text { h }\end{array}$ & $\begin{array}{l}\text { Anggot } \\
\text { a }\end{array}$ & $\begin{array}{l}\text { Jumla } \\
\text { h }\end{array}$ & $\begin{array}{l}\text { Anggot } \\
\text { a }\end{array}$ \\
\hline 1. & Sagalaherang & 20 & 406 & 23 & 442 & 9 & 139 & & \\
\hline 2. & $\begin{array}{l}\text { Serangpanjan } \\
\mathrm{g}\end{array}$ & 10 & 128 & 17 & 297 & 6 & 259 & 31 & 458 \\
\hline 3. & Jalancagak & 16 & 346 & 32 & 570 & 14 & 257 & 16 & 346 \\
\hline 4. & Ciater* & - & - & 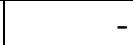 & - & - & - & - & - \\
\hline 5. & Cisalak & 0 & 0 & 21 & 172 & 9 & 72 & - & - \\
\hline 6. & Kasomalang & 13 & 118 & 23 & 278 & 8 & 79 & - & - \\
\hline 7. & Cijambe & 12 & 185 & 26 & 241 & 8 & 95 & - & - \\
\hline 8. & Cibogo & 19 & 260 & 108 & 132 & 9 & 191 & 88 & 822 \\
\hline 9. & Subang & 39 & 665 & 88 & 1.452 & 8 & 425 & - & - \\
\hline 10 & Kalijati & 27 & 318 & 48 & 513 & 10 & 22 & - & \\
\hline 11 & Dawuan & 7 & 156 & 41 & 0 & 12 & 0 & 0 & 0 \\
\hline 12 & Cipeundeuy & 11 & 154 & 15 & 215 & 6 & 50 & 65 & 247 \\
\hline 13 & Pabuaran & 8 & 65 & 4 & 62 & 16 & 539 & 5 & 25 \\
\hline 14 & Patokbeusi & - & - & - & - & - & - & - & - \\
\hline
\end{tabular}

* Tidak ada data

Sumber: Rekapitulasi Data Statistik 14 Kecamatan dalam wilayah Kabupaten Subang Tahun 2011

Kecamatan yang memiliki organisasi sosial yan paling banyak adalah Kecamatan Subang, yaitu mencapai 2677 organisasi sosial dengan pilahan terbanyak ada pada organisasi sosial bidang olahraga yaitu 1.540 organisasi sosial. Sementara kecamatan yang paling sedikit memiliki organisasi sosial adalah Kecamatan Dawuan yang hanya mencapai 216 organisasi sosial saja.

Bidang olahraga nampaknya paling diminati untuk dijadikan semacam perkumpulan atau organisasi sosial. Terbukti dari tabel 4 di atas bahwa jumlah keseluruhan organisasi sosial bidang olahraga mencapai 4.820 buah sementara organisasi sosial bidang kesenian hanya sekitar setengahnya saja yaitu berjumlah 2.983 buah. Dua bidang dalam organisasi sosial tersebut (olahraga dan kesenian) memang lebih disenangi ketimbang organisasi bidang karang taruna yang berjumlah lebih sedikit, yaitu sekitar 2.243 buah saja.

\section{Kolaborasi Seni Pertunjukan}

Kesenian daerah mulai mengembangkan sayapnya sejak ditetapkannya batik sebagai warisan budaya tak benda asli Indonesia oleh UNESCO. Memang tidak begitu 
terlihat hubungan yang signifikan tetapi setelah adanya penetapan tersebut seolah-olah telah membuka mata dari dari sejumlah pemda untuk membangkitkan kembali kesenian tradisional sebagai bagian dari kekhasan daerah mereka.

Kesenian merupakan bagian dari kebudayaan yang berkembang dinamis seiring dengan pergerakan kebudayaan. Sifat dasar kebudayaan yang dinamis ditunjang dengan keinginan manusia untuk terus berupaya memperbaiki kehidupannya baik aspek fisik ataupun psikisnya. Unsur kesenian dapat dianggap sebagai sarana ampuh untuk memperbaiki atau mengatasi permasalahan psikis manusia. Dengan melihat/mendengar/merasa atas apa yang disuguhkan dalam sebuah kesenian, manusia minimal dapat terhibur dan sedikitnya dapat lebih menyegarkan fikiran yang telah terbebani oleh berbagai macam masalah kehidupan. Yang patut dipertanyakan adalah jenis kesenian apa yang mampu menyegarkan kondisi psikis manusia?

Jazuli (2001: 81-83) membagi tiga unsur penunjang dalam kesenian, yaitu seniman, penonton atau kritikus, dan karya seni. Seniman terbagi dalam dua jenis, yaitu seniman pencipta karya (creative artist) dan seniman penafsir atau pelaku (interpretative artist). Seniman dengan pengalaman kreatifnya mengandung dua sisi, yaitu sisi subjektif dan sisi objektif. Sisi subyektif sangat dipengaruhi oleh berbagai faktor psikologis, seperti kepekaan, imajinasi, karakter pribadi, hasrat, dan berbagai pengalaman khususnya. Sisi objektif dipengaruhi oleh faktor lingkungannya, seperti lingkungan fisik, sistem nilai, pengaruh tradisi, kebutuhan sosial, bahan atau materi, iklim budaya.

Apresiasi dilakukan oleh khalayak luas (masyarakat penonton) dan kritikus sebagai penikmat dan penghayat seni. Penikmat atau penghayat seni adalah partner dari karya seni, yaitu orang yang secara langsung menghayati dalam berhadapan dengan karya seni. Nilai karya seni adalah nilai atau makna yang diciptakan oleh penikmat atau penghayatnya, yaitu setelah terjadi interaksi dengan karya seni.

Karya seni sebagai proses kreatif maupun sebagai produk yang dihasilkan oleh seniman. Suatu karya seni terwujud di dalam bentuknya yang khas dan dapat ditangkap oleh indera. Ia merupakan faktor intrinsik dari sebuah karya seni, yang dalam proses kritik disebut immanent atau aktifitas perumusan berbagai faktor objektif.

Sementara itu, jenis kesenian terbagi dalam dua bagian besar, yaitu seni pertunjukan dan seni fiskal (seni lukis dan patung). Seni pertunjukan selalu terikat oleh ruang dan waktu, sedangkan seni fiskal tidak terikat oleh ruang dan waktu dalam proses pengamatan. Oleh karenanya, proses pengamatan terhadap karya seni fiskal waktunya relatif lama sehingga banyak peluang untuk mengamati lebih cermat. 
Perbedaan yang mencolok dari karakteristik dua jenis kesenian tersebut di atas membuat berbagai proses penyempurnaan dalam upaya menarik sebanyak mungkin penonton atau penikmat seni juga sangat berbeda. Seni fiskal yang tidak terikat oleh ruang dan waktu tentunya akan sedikit mengalami penyempurnaan. Terbukti dengan beberapa aliran baru yang kemunculannya sangatlah berjalan lamban. Berbeda halnya dengan seni pertunjukan yang sangat tergantung oleh karakteristik ruang dan waktu yang sesuai agar penonton dapat lebih menikmati atau menghayati di saat pementasan. Oleh karena itu, pembahasan mengenai kolaborasi seni pertunjukan tradisional di Kabupaten Subang akan difokuskan pada kondisi lintas ruang dan lintas waktu.

\section{a. Kolaborasi Seni Pertunjukan Lintas Ruang}

Karakteristik ruang akan memunculkan istilah "kesenian daerah A atau B atau C" yang pada masing-masing daerah terlihat berbeda padahal masih dalam satu nama kesenian. Misalnya, dapat dilihat dari perbedaan antara seni topeng Betawi dan topeng Cirebon, meski nama kesenian itu adalah sama yaitu "seni topeng".

Keterikatan ruang dalam seni pertunjukan ternyata juga dapat menjadi pemicu perdebatan dalam menentukan daerah asal mula terciptanya seni pertunjukan tersebut. Ada beberapa daerah yang saling memperebutkan kepemilikan atas kekhasan kesenian mereka seperti yang terjadi antara kabupaten Sumedang dan Kabupaten Majalengka yang memperebutkan kesenian kuda renggong. Kesepakatan yang dihasilkan adalah menyerahkan sepenuhnya kesenian kuda renggong kepada Kabupaten Sumedang sebagai bagian dari kesenian tradisionalnya, sedangkan Kabupaten Majalengka membangkitkan kembali kesenian yang diberi nama Kuda Penca.

Perihal perebutan kepemilikan atas kesenian tradisional antara satu wilayah administratif dengan wilayah administratif lainnya kemungkinan akan banyak terjadi karena batasan wilayah administratif adalah tidak sama dengan batasan wilayah kesenian. Apalagi setelah adanya pemekaran yang membuat batasan wilayah kesenian tradisional terbelah dalam dua - atau bahkan lebih - wilayah administratif sehingga asal usul terciptanya suatu kesenian tradisional menjadi awal dari perseteruan antar wilayah administratif.

Melihat adanya dua pihak yang saling memperebutkan kepemilikan satu kesenian tradisional sebenarnya tidak perlu terjadi apabila melihat perjalanan kesenian yang dinamis. Artinya, bahwa pertunjukan kesenian sangat dipengaruhi oleh kepeminatan penonton yang tentunya berbeda antara daerah yang satu dengan daerah yang lain. Sering 
terjadi sisipan-sisipan yang berbeda dari satu kesenian yang dipentaskan pada wilayah yang berbeda. Tujuannya tidak lain adalah agar penonton tetap atau lebih tertarik dan akan terus menonton pertunjukan kesenian hingga akhir pementasan.

Seni Pertunjukan di Kabupaten Subang juga turut menjadi menjadi bagian menginspirasikan seni daerahnya dengan mengadopsi kesenian daerah lainnya. Sebut saja kesenian topeng jati atau topeng menor yang secara identikal ada unsur kemiripan dengan seni topeng cirebon. Perselisihan paham tidak sempat terjadi dengan Kabupaten Cirebon karena nama kesenian topeng di Subang terlebih dahulu diberi predikat tambahan, yaitu menjadi topeng jati atau topeng menor. Dalam kenyataannya, memang terdapat perbedaan antara tari topeng cirebon dengan topeng menor subang. Pemakaian topeng cirebon berjumlah 5 buah seperti yang ditampilkan dalam upacara mapag sri, yaitu topeng panji, topeng pamindo, topeng rumyang, topeng patih, dan topeng kelana (Sanny, 2009: 94). Sementara untuk topeng menor berjumlah 6 buah, yaitu: topeng Samba, topeng rumyan, topeng tumenggung, topeng buta, topeng kelana, dan topeng panji. Melihat dari perbedaan jumlah tersebut, adanya penambahan topeng buta dalam pertunjukan topeng menor subang membuat konsep tokoh dalam topeng menor menjadi lebih bervariasi. Berbeda dengan topeng cirebon, yang berjumlah lima buah, yang masing-masing memiliki arti tersendiri. Kelima unsur dalam makna topeng tersebut tergambar dalam skema yang dikemukakan oleh Soemardjo (2002: 41).

Dalam skema yang dikemukakan oleh Sumardjo, fungsi atau makna Topeng panji adalah sebagai tokoh sentral yang menjadi pusat penghubung kehidupan. Sementara empat lainnya masing-masing memiliki fungsi atau makna berbeda. Topeng Tumenggung bermakna barat, daratan akhir. Topeng Kelana bermakna selatan, dunia bawah. Topeng Pamindo Gunungsari bermakna timur, gunung, awal. Sementara yang terakhir, yaitu Topeng Rumyang Candrakirana bermakna utara, dunia atas.

Pusat merupakan dewa yang menjelma menjadi raja untuk mengatur manusianya sehingga arah lingkaran bagan tersebut melingkar ke arah kiri. Arah lingkaran yang mengkirikan pusat berarti "turun". Dari penjelasan sebelumnya, diperoleh keterangan bahwa sebelah timur yang diwakili Topeng Pamindo dan sebelah barat yang diwakili topeng rumyang, merupakan pihak keluarga dari Panji. Oleh karena itu, wilayah I pada skema menggambarkan pihak "dalam" yang feminin, bersih, halus, baik, dan sejahtera. Sedangkan, wilayah III pada bagan menggambarkan pihak "luar" yang penuh amarah, gagah, dan kasar karena dalam area inilah Panji menampakkan keberaniannya untuk 
berperang dengan Patih Socawindu dan memberantas kejahatan dalam zaman kalayuga (zaman keemasan).

Dalam skema tersebut juga terlihat bahwa Panji berada di tengah sebagai pusat sehingga dia mempunyai sifat "luar" dan sifat "dalam". Pusat merupakan peleburan, pertemuan dari keempat arah mata angin dan dapat dikatakan bahwa semua karaker yang ada dalam tari topeng Cirebon adalah Panji sendiri yang membelah diri menjadi dua pasangan yang saling bertentangan sifatnya seperti terang-gelap, perempuan-lelaki, baikjahat, siang-malam, gunung-laut, utara-selatan, barat-timur. matahari-bulan, dan daratanlautan (Sumardjo, 2004). Dualisme inilah yang menyebabkan dia dianggap sebagai asal dari semua sifat atau perwujudan Sang Tunggal. Dengan keadaan yang saling bertentangan ini, keduanya harus selalu berjalan selaras dan seimbang sehingga dapat dicapai kedamaian dunia dalam jagad kecil dan jagad gedhe.

Penggambaran penyatuan disebut sebagai Manunggal Kawula Gusti, yaitu saat alam semesta menjadi satu. Semua aspek kehidupan menyatu dengan harmonis, tidak ada yang superior maupun inferior. Terciptanya keselarasan antara dunia atas dan dunia bawah sehingga keadaan tersebut menjadi o-locus position (semua kembali kepada yang pusat), yaitu saat keselarasan terjadi karena semua kembali pada inti asalnya. Oleh karena itu, topeng dalam sebuah pertunjukan upacara juga dinyatakan sebagai ikon dengan tujuan menyatukan alam sadar dengan alam bawah sadar manusia untuk mencapai posisi suci atau Manunggal Gusti, bersatunya manusia dengan Sang Pencipta. Kesatuan antara sifat dari kelima topeng tersebut juga melambangkan arti kejiwaan atau proses kehidupan manusia dari mulai lahir ke dunia hingga ajal.

Keseluruh penjelasan tentang makna masing-masing topeng tersebut sebenarnya masih menjadi pakem dalam pertunjukan Topeng Menor namun animo masyarakat terhadap kesenian Topeng Menor sudah sangat berkurang. Kolaborasi berupa penambahan atraksi Bajidoran dan Wayangan adalah sebagai bagian dari upaya menjaring penonton untuk datang dan menyaksikan pertunjukan Topeng Menor.

Seni pertunjukan yang menggunakan topeng, selain Topeng Menor, ada juga kesenian lainnya di Kabupaten Subang, yaitu Banjet. Memang tidak menggunakan kata "topeng" dalam penamaan kesenian tersebut namun dalam pertunjukan, penarinya menggunakan topeng seperti yang dilakukan oleh grup seni topeng banjet Margaluyu.

Banjet merupakan seni pertunjukan yang kompleks karena ada unsur tari, musik, dan teater di dalamnya. Kolaborasi yang dilakukan pada grup seni Margaluyu masih sebatas penambahan waditra. Ataupun ada juga penambahan unsur cerita namun tidak 
merubah pakem seni Banjet itu sendiri. Hal ini memang sudah seharusnya dilakukan dalam seni pertunjukan dalam kategori seni teater karena sangat banyak pesan-pesan yang disampaikan dalam pentas teater rakyat tersebut. Penyampaian pesan dalam seni pertunjukan teater ini sudah lama didefinisikan oleh Ki Hajar Dewantara. Ki Hadjar Dewantara (1889-1959) sekitar setengah abad lalu telah mengemukakan bahwa nilainilai moral dapat diajarkan melalui seni pertunjukan. Sandiwara atau yang kini dikenal dengan drama disebutkan sebagai salah satu di antaranya. Tokoh pendidikan ini menyebutkan bahwa sandiwara yang berasal dari kata "sandi" yang berarti tertutup atau rahasia dan "wara" yang berarti pelajaran memiliki peran penting dalam pendidikan yang berhubungan dengan moral (Kusmayati, 2006, 7 - 9.).

Sebenarnya bukan hanya seni Banjet yang mengandung unsur teatrikal atau drama, wayang golek juga sarat dengan berbagai macam cerita pewayangan yang cukup lengkap mulai dari pembukaan, permasalahan, dan penyelesaian masalah. Dua seni pertunjukan yang berbeda pelaku namun banyak memiliki kesamaan. Dalam banjet juga ada sandiwara yang lengkap dengan masalah dan diakhiri dengan penyelesaian masalah. Di antara scene-scene adegan - banjet dan wayang golek - terselip adegan-adegan yang mengundang gelak tawa. Tidak ada unsur makna yang mendalam dalam adegan humor tersebut karena lebih diutamakan sebagai sarana pelepas lelah para penonton setelah secara serius mengikuti jalannya cerita. Dengan demikian, inti dari kolaborasi dari kedua seni pertunjukan tradisional ini mengacu pada upaya menarik minat penonton dengan cara menambahkan atribut-atribut (materi ataupun improvisasi) agar dapat lebih mengundang kelucuan.

\section{b. Kolaborasi Seni Pertunjukan Lintas Waktu}

Beranjak pada pendalaman masalah ruang dan waktu pada seni pertunjukan akan sangat berpedoman pada istilah "dulu" dan "sekarang". Istilah "dulu" dan "sekarang" juga menampilkan efek perubahan atau perbedaan dari seni pertunjukan. Perjalanan waktu yang dipadu dengan perjalanan selera penonton adalah tema sentral dari perubahan berupa penambahan atau pengurangan beberapa tahap dalam seni petunjukan.

Satu kesenian daerah Kabupaten Subang yang cukup terkenal dan menjadi maskot Subang, yaitu Sisingaan yang telah mengarungi berbagai macam masa pemerintahan dan peristiwa. Terciptanya kesenian Sisingaan sebagai wujud kemarahan rakyat Subang terhadap penjajah sebenarnya merupakan salah satu dari sekian banyak alasan terciptanya sebuah kesenian yang bernama Sisingaan. Perjalanan waktu membuat 
makna atau alasan terciptanya kesenian Sisingaan menjadi berubah-ubah. Wajar terjadi adanya perubahan makna atau alasan tersebut karena perjalanan sebuah kesenian daerah selalu mengikuti perjalanan sosial dan budaya masyarakat atau penontonnya. Di lain pihak, masyarakat adalah suatu sistem yang secara keseluruhan terdiri dari bagian-bagian yang saling bergantung, dan keseluruhan atau sistem yang utuh itu menentukan bagianbagian. Oleh karena itu, ada saling ketergantungan antara kesenian dengan masyarakat. Dari pihak pelaku seni, kehadiran penonton yang melimpah ruah adalah sebuah kepuasan tersendiri yang tidak dapat diukur dengan materi. Sementara itu, dari pihak masyarakat, kesenian dapat menjadi salah satu pemenuhan aspek hiburan, sakral dan presentasi.

Hiburan adalah kata yang tepat untuk melihat pertunjukan Sisingaan. Kemasan yang dibuat sedemikian rupa membuat pertunjukan Sisingaan terlihat lebih menarik jika dibandingkan dengan pertunjukan pada awal terciptanya seni Sisingaan. Oleh karena itu, tidak heran apabila banyak pihak yang mengundang kesenian Sisingaan untuk berbagai acara mulai dari hajatan, hingga pergelaran yang bersifat resmi.

Melihat perjalanan waktu yang ditandai dengan penggunaan atribut-atribut yang semenarik mungkin seakan fungsi Sisingaan lebih condong pada fungsi hiburan sementara fungsi lainnya hanya merupakan pelengkap saja. Dengan demikian, seni pertunjukan Sisingaan lebih bersifat presentasi estetis. Maksudnya, jenis-jenis dan bentuk-bentuk yang dinikmati nilai keindahannya semata-mata dengan mengabaikan kepentingan yang lain. Akibatnya, unsur magis ataupun makna yang terkandung dalam tiap adegan kesenian Sisingaan sudah diselubungi oleh unsur hiburan. Padahal nuansa kesakralan dalam seni pertunjukan selain diperlihatkan dalam beberapa adegan juga mengandung simbol-simbol mistis dengan tujuan untuk memuliakan arwah leluhur dan kekuatan alam yang disakralkan. Pemuliaan arwah bukan diartikan dalam arti sempit karena akan terjerumus dalam tatanan nilai lama yang cenderung menduakan keagungan Tuhan Yang Maha Esa. Pemuliaan arwah yang dimaksud dalam konsep pertunjukan kekinian lebih ditujukan kepada doa keleluasaan dari arwah leluhur agar mendapat tempat yang layak di sisi-Nya. Sementara itu, seni pertunjukan tradisional yang sudah dikenal mampu menjadi wadah bermacam-macam pesan pada saat ini nampak sudah kehilangan pamornya. Atribut dan kolaborasi yang saat ini diterapkan tidak saja dalam kesenian Sisingaan, membuat tangkapan nilai dan makna oleh para penonton menjadi tidak begitu tajam karena terhalang oleh merdunya iringan musik dan atraksi yang memukau.

Kolaborasi seni pertunjukan dalam menjaring penonton yang lebih condong pada aspek hiburan juga dilakukan pada seni Toleat. Kreativitas Parman (pencipta seni Toleat) 
dalam menggabungkan empet-empetan dan ole-olean menjadi satu alat seni yang bernama Toleat didasarkan atas keahlian Parman dalam memainkan terompet sehingga karakteristik Toleat memiliki persamaan dengan terompet. Nada suara yang dihasilkan kemudian dikolaborasikan dengan berbagai alat musik tradisional sehingga menghasilkan sebuah pertunjukan yang sangat menarik.

Berbeda dengan seni pertunjukan lainnya yang lebih kompleks, Toleat hanyalah sebuah waditra unik yang akan bersuara merdu apabila digabungkan dengan waditra lainnya. Ataupun akan semakin marak bila ada tarian dan nyanyian yang diiringi alunan Toleat. Memang seni Toleat ini adalah bentukan baru yang jelas runtutan peristiwa berikut penciptanya. Sehingga sangat sulit untuk menyatakan bahwa Toleat adalah sebuah alat seni tradisional. Namun demikian, Penciptaan Toleat itu sendiri adalah sebuah kolaborasi dari dua alat musik tradisional yang cukup pintar untuk menyelaraskan nada suara agar lebih enak didengar dan daya tahan alat yang lebih tahan lama.

\section{PENUTUP}

Wilayah Geografis Kabupaten Subang yang turut menentukan kondisi seni pertunjukan, yaitu wilayah perbukitan, persawahan, perladangan, dan pesisir pantai. DI antara empat wilayah geografis tersebut, wilayah pesisir pantai merupakan ruang terbuka yang paling banyak mendapat kunjungan pengaruh budaya luar sehingga rentan terkena imbas budaya global, sementara tiga wilayah lainnya tergolong masih belum begitu banyak mendapatkan efek budaya global. Meskipun demikian, tiga wilayah geografis di Kabupaten Subang tersebut saat ini bukan berarti tidak dapat dipengaruhi oleh unsur baru yang masuk dan berakulturasi negatif terhadap unsur budaya lama. Saat ini teknologi komunikasi sudah masuk begitu dalam sehingga bentuk baru dari berbagai unsur budaya dengan mudah masuk. Piliang (dalam Ayawaila, 2009: 51) mengatakan bahwa adanya pergeseran bentuk dan makna dari kesenian rakyat, yang mengakibatkan terperosoknya sejumlah kesenian lokal ke dalam hegemoni industri budaya. Kenyataan yang dikemukakan oleh Piliang tersebut saat ini juga sudah terjadi di Kabupaten Subang. Kolaborasi yang terlalu berlebihan terkadang dapat merusak tatanan standar seni pertunjukan yang seharusnya dijaga. Saat ini, kolaborasi yang telah dilakukan dalam berbagai jenis seni pertunjukan di Kabupaten Subang sudah masuk dalam setiap lini mulai dari tahap pertunjukan, tata rias dan busana, koreografi, dan pendukung pertunjukan. Di antara seni pertunjukan di Kabupaten Subang, seni pertunjukan Sisingaan 
sudah mendapat pengaruh kolaborasi yang paling banyak hingga di setiap lini. Berbeda halnya dengan seni gembyung yang masih dapat menjaga kadar keasliannya sehingga penonton dapat merasakan aura magis baik saat menonton ataupun ikut berpartisipasi dalam tariannya.

Dua seni pertunjukan tersebut di atas, yaitu Gembyung dan Sisingaan, tampaknya mempunyai misi yang berbeda dari awal penciptaannya. Gembyung - begitu juga halnya dengan ketuktilu - tercipta sebagai sebuah kesenian yang awalnya dikhususkan bagi kalangan pesantren sehingga kadar kolaborasi yang masuk masih mendapat pengawasan yang cukup ketat agar tidak menyimpang dari pakem. Berbeda dengan kesenian Sisingaan yang diciptakan sebagai sarana penghibur rakyat yang tertindas. Kata "menghibur" tersebut menjadi acuan hingga saat ini. Nilai atau makna yang muncul belakangan hanyalah sebagai acuan tambahan agar seni Sisingaan tidak hanya melulu unsur hiburan semata.

Hiburan tampaknya menjadi unsur utama yang menjadi acuan kolaborasi dalam seni pertunjukan di Kabupaten Subang. Tanggapan positif dari pegiat seni dan instansi terkait yang memang ingin menjadikan Kabupaten Subang sebagai salah satu base camp seni pertunjukan di Jawa Barat menjadi tolok ukur terhadap perkembangan dunia seni pertunjukan di Subang Itu sendiri. Walaupun demikian, jauh sebelum kolaborasi itu lahir penciptaan seni pertunjukan memiliki misi yang mulia. Tidak hanya menjadi sarana hiburan semata namun terkait dengan berbagai unsur yang bermuara pada ketenangan jiwa penonton. Sebuah upaya seni yang tidak hanya melulu mengandalkan unsur hiburan semata tetapi di dalamnya juga harus terdapat unsur religi dan kandungan makna yang mendalam agar penonton dapat berbicara pada dirinya sendiri mengenai apa yang telah dan akan diperbuat untuk kebaikan hidupnya. Rupanya, unsur religi dan kandungan makna nampak luput dalam pandangan kolaborator seni pertunjukan sehingga lambat laun arahan yang dicapai hanyalah unsur hiburan semata. Atau dengan kata lain, unsur hiburan lebih diutamakan daripada unsur pendidikan pekerti. Dengan demikian, setelah selesai pertunjukan, penonton tidak mendapatkan makna yang dapat direnungkan setelah melihat seni pertunjukan tersebut. Parahnya lagi, seperti yang dikemukakan oleh Ayawaila (2009: 51) bahwa berbagai proyek pengembangan seni pertunjukan tradisi yang dikemas untuk kepentingan pengembangan usaha pariwisata nasional, diasumsikan menghasilkan anggaran besar yang sulit dideteksi aliran penggunaannya. Proyek itu hanya dapat dinikmati oleh sebagian birokrat yang terlibat dalam proyek pariwisata 
tersebut. Sedangkan masyarakat lokal pegiat seni pertunjukan tradisi tidak mendapatkan sesuatu yang positif bagi keberlangsungan eksistensi keseniannya.

Walaupun ada tanggapan bernada miring dari Ayawaila, namun penulis masih tetap yakin bahwa instansi terkait yang menangani seni pertunjukan di Kabupaten Subang memiliki tujuan positif yang dapat berpegang pada prinsip win win solution. Pariwisata memang menjadi andalan devisa bagi kabupaten yang sarat dengan kekayaan seni budayanya. Dengan demikian, manajemen pengolahan seni pertunjukan yang bersifat merakyat agaknya merupakan cara ampuh untuk menjadikan seni pertunjukan sebagai salah satu sumber penghasilan dengan tidak menghilangkan pakem positif yang menjadi modal dasar sejak awal dari penciptaan seni pertunjukan itu sendiri.

Pilahan-pilahan kolaborasi dengan demikian harus mengandung unsur pendidikan pekerti yang harus dituangkan secara transparan kepada penonton yang saat ini sudah semakin kritis (lebih pandai memilah dan mengungkapkannya dalam berbagai media). Unsur hiburan yang menjadi modal dasar para kolaborator seni sudah seharusnya melihat unsur etika dan estetika seni sehingga sebuah seni pertunjukan hasil kolaborasi tidak saja dapat dinikmati oleh masyarakat setempat, tetapi juga masyarakat dalam wilayah administratif atau kebudayaan lainnya tanpa menimbulkan pertentangan baik dari segi visual ataupun kaidah seni pertunjukan itu sendiri.

\section{DAFTAR SUMBER}

Ayawaila, Gerson R. 2009.

"Merepresentasikan Seni Pertunjukan Tradisi melalui Pendekatan Etnodokumenter", dalam Dewa Ruci Vol. 6 No. 1 Desember 2009.

Jazuli, M.. 2001.

"Kritik Seni Pertunjukan (Critic of The Performing Art)", dalam Harmonia Jurnal Pengetahuan dan Pemikiran Seni Vol.2 No.2/Mei-Agustus 2001

Kusmayati, A.M. Hermien, 2006.

“Aspek Etika dalam Bingkai Seni Pertunjukan”, dalam pidato pengukuhan Guru Besar pada Fakultas Seni Pertunjukan Institut Seni Indonesia Yogyakarta, 25 Maret 2006.

Sany, Yudhanty Parama. 2009. 
"Topeng dan Pertunjukannya dalam Upacara Adat Mapag Sri: Ikon Masyarakat Desa Pangkalan, Kabupaten Cirebon". Skripsi, Depok: FISIP Jurusan Antropologi Universitas Indonesia.

Sedyawati, Edi. 1992.

"Sistem Kesenian Nasional Indonesia: Sebuah Renungan". dalam Pidato Upacara Pengukuhan Jabatan Guru Besar Tetap Fakultas Sastra Universitas Indonesia. Jakarta: Universitas Indonesia.

Shahab, Yasmine Z. 2004.

"Seni sebagai Ekspresi Eksistensi Tantangan Kebijakan Multikulturalisme". dalam Antropologi Indonesia 75, 2004

Soemardjo, Jakob. 2002.

"Tafsir Kosmologi Topeng Cirebon", dalam Pergelaran Topeng Cirebon. Bandung: Produksi Studio Tari Jurusan Tari STSI Bandung. , 2004.

Perkembangan Teater Modern dan Sastra Drama Indonesia. Bandung: STSI Press.

Sudjana K. 1974.

"Banjet", dalam Buletin Kebudayaan Jawa Barat. Bandung: Proyek Penunjang Peningkatan Kebudayaan Propinsi Nasional Jawa Barat.

Widaryanto, F. X. tt.

Mitos, Seni, dan Kehidupan (Sebuah Pengantar). Makalah.

Yoeti, O.A. 1985.

Melestarikan Seni Budaya yang Nyaris Punah. Bandung: Depdikbud. 